\title{
Thousand-year-old depictions of massage abortion
}

\author{
Malcolm Potts, Maura Graff, Judy Taing
}

\section{Background}

Abortion induced by physical trauma has a long history. This article describes bas-relief sculptures in Angkor Wat, Cambodia dating from the 9th to the 12th centuries, and compares them to contemporary observations of massage abortion. The Cambodian carvings, along with two similar representations in Indonesia, are the earliest known illustrations of an abortion in progress. The bas-reliefs prove that abortion techniques were well understood at the time, although their cultural interpretation is uncertain.

\section{Massage abortion}

Massage abortion is widely practised in present day Southeast Asia, from Myanmar, through Thailand, down to Malaysia, and across to Indonesia and the Philippines. ${ }^{1}$ In Malaysia it is called bomo. In the Philippines a hilot, or traditional birth attendant (TBA), is the person who usually conducts the procedure. Narkavonnakit interviewed 81 abortion practitioners in Thailand and found almost half of all abortions were by massage. She estimated that several hundred thousand massage abortions were being performed in rural Thailand each year. ${ }^{2}$

In Southern Nigeria, traditional abdominal massage techniques are used for a variety of obstetric conditions, such as cephalopelvic disproportion. In approximately $20 \%$ of cases it is practised early in pregnancy, and possibly perceived as an abortion technique. ${ }^{3}$

The crude application of force to induce abortion has been observed in many preliterate societies. ${ }^{4}$ Massage abortion does not involve any vaginal manipulation and the pregnancy must be sufficiently advanced for the fundus uteri to be palpable from above the symphysis. The TBA attempts to stabilise the uterus (Figure 1) and then begins to put increasing pressure on the abdominal wall. She may use her fingers, her elbows, her feet, or even the pestle many village women own to pound rice. The pressure is continued until vaginal bleeding is observed.

Some abortions occur within minutes, but sometimes the procedure is continued for much longer and occasionally leads to internal haemorrhage. Surgeons report admitting women with board-like abdominal rigidity, a low fever and rebound tenderness. On opening the abdomen expecting to find an inflamed appendix, they observe instead a bruised uterus. Sometimes hysterectomy is necessary.

Gallen studied massage abortion in rural and urban areas in the Philippines and noted that both clients and practitioners regarded it as "a very painful procedure". 5 The Filipino operators were over $80 \%$ Roman Catholic and some said they prayed while performing the massage. 5 The TBA in Figure 1, who had an urban practice, reported "doing about one massage abortion a day for 10 years".

J Fam Plann Reprod Health Care 2007; 33(4): 233-234

University of California at Berkeley, School of Public Health, Berkeley, CA, USA

Malcolm Potts, MB BChir, PhD, Bixby Professor

Maura Wilde Graff, MPH candidate, Research Officer

Judy Taing, Research Assistant

Correspondence to: Professor Malcolm Potts, University of California at Berkeley, School of Public Health, 513 Warren Hall, Berkeley, CA 94720, USA. E-mail: pottsmalcolm@yahoo.com

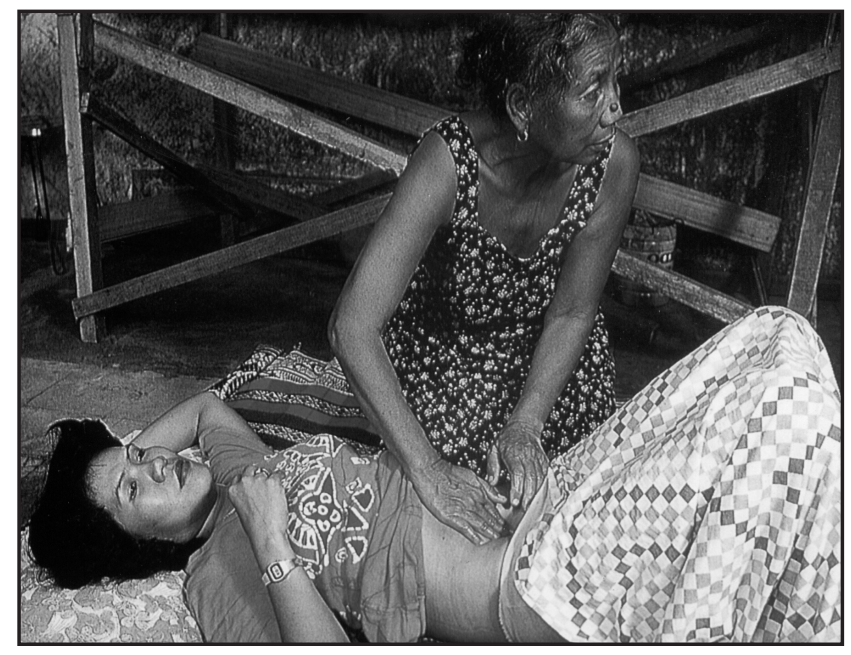

Figure 1 Massage abortion by a traditional midwife. Manila, Philippines, C. AD 1978. Photograph by Joe Cantrell

\section{The Angkor Wat bas-reliefs}

The Angkor's civilisation began to flourish in the 9th century AD near the shores of the Great Lake (Tonle Sap). ${ }^{6}$ A strong monarchy reached its apogee under King Suryavarman II (AD 1113-1150), the primary builder of Angkor Wat.

Angkor Wat is an expression in stone of a well-ordered celestial kingdom, and it brings together both Hindu and Buddhist teachings. ${ }^{7}$ A series of $2.43 \mathrm{~m}$ (8 feet) high basrelief sculptures cover the entire outer surface of the temple's $1600 \mathrm{~m}$ (5250 feet) perimeter wall. The reliefs are exquisitely carved in the outer half-inch of the sandstone walls, and they glow with reflected sunlight, which illuminates complex scenes unfolding continuously for up to $100 \mathrm{~m}$

In the South-Eastern gallery, a panel $64.4 \mathrm{~m}$ (214 feet 6 inches) long represents the judgment of mankind after death. ${ }^{8}$ There are 32 representations of hell, most identified with a brief description in Sanskrit, although it is possible these inscriptions were added some centuries later. Each hell is portrayed as a tableau and the images appear to be tailored to treat the perpetrators of specific crimes. The carvings of massage abortion appear in the thirty-second hell. Women are piled up like cordwood, naked with bound hands, and each is about 20 weeks pregnant (Figure 2). The male figures in the reliefs are pounding the abdomen of a pregnant woman with a pestle. Immediately to the left of the massage abortion scene, two torturers are loading another pregnant woman on a pile and women are being stacked in a horizontal position over flames.

Similar, although artistically cruder, representations of massage abortion have been found in the Indonesian temples of Borobudur (built by the Shailendra dynasty, AD 750-860) ${ }^{9}$ and Prambanan (AD 900). Both temples share an architectural plan with Angkor, and have bas-relief sculptures to depict religious teachings. Both also locate their images of massage abortion among representations of the afterlife. Although photographed 100 years ago, the bas-relief sculptures at Borobudur are currently buried beneath a raised footpath, supposedly put there to prevent subsidence. ${ }^{10,11}$ Some of the accompanying inscriptions may have been lost. At Prambanan, a bas-relief sculpture tells the story of a king warned by a prediction that he 


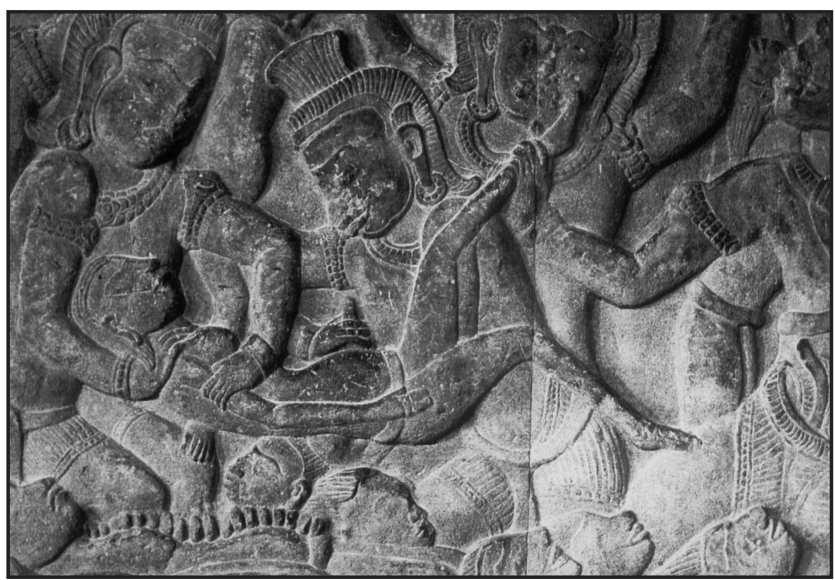

Figure 2 Bas-relief of a massage abortion. The abdomen of the pregnant woman is darkened as a result of being touched by numerous pilgrims. Angkor Wat, Cambodia, C. AD 1150. Photograph by Malcom Potts

would be killed by a child of his sister. His sister's pregnant belly is being hit by the hands of a woman whose face is contorted with a frightening expression. The pregnant sister leans back but cannot escape the blows. ${ }^{12}$

\section{Interpretation}

Clearly, the method of abortion illustrated in the 1000-year old bas-reliefs is identical to that used today, even if the procedure has been transposed to the afterlife and, at least at Angkor, the operator is a demon and not a TBA. The carvings attest to the antiquity of the massage abortion technique and also strongly suggest that most people were sufficiently familiar with the method to identify with the illustrations on the frieze.

Each hell in the Angkor frieze is tailored to treat the perpetrators of specific crimes. The inscription over the thirty-second hell in the Angkor carvings is: "The hell of the violent, the miserly, the creditors without pity". 12 The thirty-second hell is also known by the name given by French archaeologists, L'enfer Raurava, the Hell of Groaning or the Hell of Screaming.

For medieval Christendom, hell was eternal torture, but in Hindu (and Buddhist) theology, with its belief in reincarnation, hell represented a process of atonement. The 32 hells on the Angkor frieze may be considered as a series of soul-surgery theatres where the work of purifying a person proceeds. For the women in the thirty-second hell, the abortion could be interpreted as a remedy for some other sin the woman committed, or the women could be undergoing punishment because they had an abortion while alive.

Hindu and Buddhist societies, like many others, provide contradictory messages about abortion. The Susruta Samhita, the earliest medical text, advocates abortion to prevent a woman dying in childbirth. At the same time abortion was condemned in the Hindu legal code of 1200 BC, and the Athara Veda (1000 BC) has the invocation: "Wipe off, O Pushan, the misdeeds of him who practiseth abortion". Similarly, Buddhist texts, like those ascribed to Hippocrates, both describe how to do abortions and also condemn the procedure. The Pali $V i n a y a$, a legal text from Northern India dating from the 5 th century BC, describes the use of abortifacients. One pregnant woman asks a monk: "Look here, master, find me an abortive preparation". "Well then, destroy it, sister", replies the monk. The word for destroy can also be translated as crush or bruise, and may refer to massage abortion. ${ }^{13}$
Although the Angkor frieze may portray abortion as part of a purifying punishment, the more likely interpretation is that the carvings are intended to portray a punishment for abortion. The now-concealed carvings at Borobudur are thought to depict passages from the Karmavibhangga, a sermon attributed to Buddha on the "great classification of actions". The massage abortion is found in a panel showing wicked deeds that led to a short life in the next reincarnation of the person who perpetuated the deed.

\section{Conclusions}

The specific technique of massage abortion appears to date back more than 2000 years and the Borobudur and Angkor bas-reliefs are the oldest representations of the technique known. Oddly, although often a relatively effective technique, massage abortion is not widespread outside the confines of the Hindu and Buddhist worlds.

Abortion by a variety of means is known in all societies and all phases of history, and it is commonly condemned by law and or religious teaching. Abortion is mentioned in the Sumerian Code (2000 BC), the Assyrian Law (1800 BC) and the Code of Hammurabi (1300 BC). Abortion resulting from trauma is mentioned in the Old Testament, where if men who are fighting injure a pregnant woman and she miscarries then they shall pay a fine. ${ }^{14}$ If, however, the woman dies, then they must give "a life for a life". Interestingly, this is the only explicit reference to abortion in the Old or New Testament, and it is notable that abortion itself is not considered murder.

The Angkor carvings underscore the universality of abortion. For hundreds of millions of women, the torments it was imagined women might suffer in hell for terminating a pregnancy are a reality on earth.

\section{Acknowledgement}

Part of the background research for this article was done by David Handel, MA, who died in 2003.

\section{Statements on funding and competing interests}

Funding None identified.

Competing interests None identified.

\section{References}

1 Flavier JM, Chen $\mathrm{CH}$. Induced abortion in the villages of Cavite, the Philippines: knowledge, attitudes and practice. Stud Fam Plan 1980; 11: 65-71.

2 Narkavonnakit T. Abortion in rural Thailand: a survey of practitioners. Stud Fam Plan 1979; 10: 223-229.

3 Ugbomo HA, Akani Cl. Abdominal massage: another cause of maternal mortality. Niger J Med 2004; 13: 259-262.

4 Devereux G. A Study of Abortion in Primitive Societies: A Typological, Distributional, and Dynamic Analysis of the Prevention of Birth in 400 Preindustrial Societies. New York, NY: Julian Press, 1955.

5 Gallen M. Abortion Practices in the Philippines: An Exploratory Study Among Clients and Practitioners. Washington, DC: International Committee on Applied Research in Population, 1980.

6 Van Liere J. Traditional water management in the Lower Mekong Basin. World Archaeol 1980; 2: 265-280.

7 Mazzeo D, Antonini CS. Ancient Cambodia. New York, NY: Grosset and Dunlap, 1978.

8 Dickason DH. Wonderous Angkor. Shanghai, China: Kelly \& Walsh, 1937.

9 Krom NJ. Barabudur: Archaeological Description. The Hague, The Netherlands: M Nyhoff, 1927.

10 Krom NJ. Levensgeschiedenis van den Buddha op Barabudur. Delhi, India: Bhartuya Publishing House, 1974.

11 Fontein J. The Sculpture of Indonesia. Washington, DC: National Gallery of Art, 1990.

12 Aymonier EF. Les inscriptions modernes d'Ankor Vat; Preah Pean, Bakan et la grande inscription. Paris, France: Imprimerie Nationale, 1900.

13 Perera LPN. Sexuality and the Women in Buddhism. Colombo, Sri Lanka: Karunaratne \& Sons, 1995.

14 Exodus $21: 23$ 